


\title{
CHAPTER 88
}

\section{RESEARCHES ON SEA-WALLS}

\author{
5 Nagai \\ Professor of Hydraulics, \\ Dean of Faculty of Englneering, \\ Osaka Cıty Unıversıty, Osaka, Japan
}

\section{ABSTRACT}

In the recent decade, very wide areas of sea where the depths of water are from several meters to ten meters or more during storms have been reclaimed for industrial firms and port facilities in many places in Japan As the incident wave energy in such cases is very large at the sea-walls, the protection of the reclaimed lands from wave overtopping by the conventional sea-walls of vertical type or composite-slope-and-berm type is generally impossible from an economical point of view In Japan a special type of sea-wall, which is of such a type that a rubble-mound covered with specially shaped precast concrete armor blocks is built in front of the sea-wall to absorb most of the incldent wave energy, has been constructed to protect the reclaimed lands from wave overtopping Most of the seawalls have been proved satisfactory after passing of typhoons over or near the sea-walls The design of the sea-walls is presented here in by showing the comparisons between the experıments and prototypes during typhoons

\section{INTRODUCTION}

Until about fifteen years ago most of sea-walls had been bullt on the shore line or in shallow water for the protection of low lands or coastal areas from the attack of high tides and storm waves In such cases incoming wave energy is generally not large and the sea-walls can be designed only with the estimations of the change of the incoming wave characteristics before the waves reach the sea-walls and of the wave run-up on the sea-walls In a recent decade, however, very wide areas of sea where the depths of water are several meters to ten meters or more during typhoons or storms have been forced to reclaim at many place in Japan, because of rapid expanding industries and increasing population In the latter cases the incident wave energy at the sea-walls is much larger than that in the former cases, and the protection of the reclalmed land from wave overtopping during typhoons is so difficult that a conventional sea-wall of vertical type would need very high crowns with heights of two to several times the design wave height above the design sea level or a seawall of composite-slope and berm type would require a very large crosssection Therefore the sea-walls of these two types are seldom possible to be designed from an economical point of view

In Japan a special type of sea-wall has been constructed since around 1961 to protect reclaimed lands and coastal areas from wave overtopping It is of such a type that a rubble-mound covered with specially shaped precast concrete armor blocks is built in front of the sea-wall in order to absorb most of the incoming wave energy

The comprehensive experiments of the sea-walls of this type have been performed since 1960 in wind channels with a wind blower in Osaka City University, and numerous sea-walls have been designed and constructed in seas since 1961 by the use of the experimental results Most of the 
sea-walls have proved after attacks of storm waves during typhoons that the results obtained in the experiments were in a good agreement with prototype

\section{PARAMETERS REIATED WITH WAVE OVERTOPPING AND CLASSIFICATION OF OVERTOPPING}

In the investigation to determine the quantity of wave overtopping from the sea-walls of special type mentioned above the following variables should be considered

$q$ = quantity of overtopplng over the unit length of the sea-wall for a period,

$H=$ helght of the incoming wave,

$I=$ length of the lncoming wave,

$h_{1}=$ depth of water at the toe of the rubble-mound,

$\mathrm{H}_{\mathrm{C}}=$ height of the crown of the sea-wall above the design sea level,

$\mathrm{H}_{\boldsymbol{r}}=$ helght of the crown of the rubble-mound above the design sea level,

1 = slope of the sea bottom

$\tan \alpha=$ slope of the rubble-mound,

B = width of the crown of the rubble-mound, and

$\mathrm{V}=$ wind velocity

These symbols are shown in Fig 1

If $q_{0}$ defines the volume of water transported shoreward by a shallow water wave for a period, it is given by the small amplitude wave theory

$$
\begin{aligned}
q_{0} & =\int_{0}^{T / 2} \int_{h_{1}}^{0} u \text { dzdt } \\
& =\int_{0}^{T / 2} \int_{h_{1}}^{0} \frac{H}{2} \frac{2 \pi}{T} \frac{\cosh \frac{2 \pi}{L}\left(h_{1}+Z\right)}{\sinh \frac{2 \pi}{L} h_{1}} \sin \left(\frac{2 \pi}{L} \times-\frac{2 \pi}{T} t\right) d z d t \\
& =\frac{H L}{2 \pi}
\end{aligned}
$$

If $q / q_{0}$ is used as a dimensionless parameter of wave overtopping, it is a function of the following dimensionless parameters

$$
q / q_{0}=f\left(h_{1} / H, h_{1} / L, H_{C} / H, H_{r} / H, B / H, 1, V / \sqrt{g H}, \tan \alpha\right) \cdots \cdots \cdot(1)
$$

when the permeabllity and roughness of the rubble-mound are kept constant

The dissipation of the energy of a wave striking the sea-wall with a rubble-mound covered with specially shaped precast concrete armors depends, to a considerable extent, on the characteristics of the armor biocks, that 1s, the permeability, the distribution of the volds of the armor layers and the roughness of the armors, as well as the slope of the rubble-mound, $\tan \alpha$, and the crown width, B In practical designs the value of tan $\alpha$ has mostly been taken 115 or 12 from an economlcal polnt of view and the stablilty of the armor blocks used on the slope The crown wldth, $B$, of the rubble-mound also has usually been taken the width of two to three rows of the armor blocks from the same reasons as mentioned above 
Therefore $\tan \alpha$ was kept 115 in our experiments, and most of $B$ were taken four to six meters in prototype-scale The velocity of wind has a great effect on the quantity of overtopping of a sea-wall when it exceeds about ten meters per second, but $1 t$ was kept constant $v=20$ to 25 meters per second in the experiments According to the results of the experiments, in which $\mathrm{B} / \mathrm{H}$ ranged from 10 to 40 , and $\mathrm{V} / \sqrt{\mathrm{gH}}$ were proved to have a negligibly small effect on overtopping Finally the relative overtopping was shown as a function of the following five major dimensionless parameters

$$
q / q_{o}=f\left(h_{1} / H, H / L, H_{C} / H, H_{r} / H, 1\right), \ldots \ldots \ldots \ldots \ldots \ldots \ldots \ldots
$$

when the shape and hydraulic characterlstics of the rubble-mound is kept constant

When the depth of water at the toe of the rubble-mound, $h_{l}$, is so small that the incoming wave breaks offshore the rubble-mound, it is rather easy to construct a sea-wall whlch can completely prevent the overtopping even during windy storms However, when $h_{1}$ is equal to or larger than the depth of breaking of the incoming wave, it is generally seldom possible from anc economical point of view to design a sea-wall of no-overtopping As $h_{1}$ increases compared with $H$, the difficulty increases much more, and it cannot be helped to permit some quantity of overtopping from the seawall The quantity of overtopping to be allowed depends upon the economical value of the land to be protected, the purpose of use of the area, the stabllity of the sea-wall and the scale of the drainage channel. According to the results of the experiments, the state and quantity of the overtopping can be classified into the four cases shown in Table 1 by the value of $q / q_{0}$

TABLE 1 CLASSIFICATION OF BEHAVIORS OF OVERTOPPING

\begin{tabular}{|c|c|c|c|}
\hline $\begin{array}{l}\text { Classifi- } \\
\text { cation }\end{array}$ & Behavior of overtopping & $q / q_{0}$ & $\begin{array}{l}\text { Propr1- } \\
\text { ety }\end{array}$ \\
\hline I & $\begin{array}{c}\text { Only spray overtops } \\
\text { (very well absorption of wave) }\end{array}$ & $10^{-4}$ & \multirow{2}{*}{$\begin{array}{l}\text { Ade- } \\
\text { quate } \\
\text { for a } \\
\text { sea-wall }\end{array}$} \\
\hline II & $\begin{array}{l}\text { Lumps of water overtop (hlgher } \\
\text { limlt applicable to a sea-wall) }\end{array}$ & $\begin{array}{l}10^{-4} \text { to } \\
5 \times 10^{-3}\end{array}$ & \\
\hline III & $\begin{array}{l}\text { A substantial part of wave over- } \\
\text { tops (1mperfect absorption of wave) }\end{array}$ & $\begin{array}{l}5 \times 10^{-3} \\
\text { to } 10^{-2}\end{array}$ & \multirow{2}{*}{$\begin{array}{l}\text { Inad- } \\
\text { equate } \\
\text { for a } \\
\text { sea-wall }\end{array}$} \\
\hline IV & $\begin{array}{l}\text { Large volume of wave overflows } \\
\text { (poor absorption of wave) }\end{array}$ & $\begin{array}{c}10^{-2} \text { to } \\
10^{-1}\end{array}$ & \\
\hline
\end{tabular}




\section{EXPERIMENTAL EQUIPMENT AND PROCEDURES}

The experiments were performed by dividing into two groups, one was concerned with sea-walls constructed in comparatively shallow waters with depths less than several meters, and the other concerned with seawalls bullt in deeper waters with depths from about 8 meters to 14 meters The former group of the experiments were conducted in 1963 and 1964, and the latter in 1966 and 1967 The wave channel used for both groups of the experiments is $50 \mathrm{~m}$ long, $1 \mathrm{~m}$ wide, and $165 \mathrm{~m} \mathrm{~h} 1 \mathrm{gh}$, and has a wind blower by which winds of velocities up to $60 \mathrm{~m}$ per sec can be blown over the water waves generated by a wave-generator of flutter-type The scale of the experiments used in both the groups 1 s $1 / 20$ horizontally and vertically The characteristics of the waves tested and other conditions used in the experiments are summerized in Table 2 The $10 \mathrm{~m}-$ length of the bottom in front of the sea-wall has a slope of 1 , and the remaining part of the bottom is flat

TABLE 2 CONDITIONS USED IN EXPERIMENTS

\begin{tabular}{|c|c|c|c|c|c|c|c|c|c|}
\hline \multirow{3}{*}{$\begin{array}{l}\text { Group } \\
\text { of } \\
\text { exper- } \\
\text { Iment }\end{array}$} & \multicolumn{2}{|c|}{ water depth } & \multicolumn{4}{|c|}{$\begin{array}{c}\text { Wave } \\
\text { characteristics }\end{array}$} & \multirow{2}{*}{$\begin{array}{c}\text { slope } \\
\text { of } \\
\text { bottom }\end{array}$} & \multicolumn{2}{|c|}{ Wind velocity } \\
\hline & model & $\begin{array}{l}\text { proto- } \\
\text { type }\end{array}$ & & del & $\begin{array}{r}\text { pro } \\
\text { ty }\end{array}$ & co- & & model & $\begin{array}{l}\text { proto- } \\
\text { type }\end{array}$ \\
\hline & $\underset{\mathrm{cm}}{\left(\mathrm{h}_{1}\right) \mathrm{m}}$ & $\underset{m}{\left(h_{1}\right) p}$ & $\mathrm{Hm}$ & $\begin{array}{l}\text { Tm } \\
\text { sec }\end{array}$ & $\begin{array}{r}\text { Hp } \\
\text { m }\end{array}$ & $\begin{array}{l}\text { Tp } \\
\text { sec }\end{array}$ & 1 & $\begin{array}{c}\mathrm{Vm} \\
\mathrm{cm} / \mathrm{sec}\end{array}$ & $\begin{array}{l}\mathrm{Vp} \\
\mathrm{m} / \mathrm{sec}\end{array}$ \\
\hline $\begin{array}{l}\text { Shal- } \\
\text { lower } \\
\text { waters }\end{array}$ & $\begin{array}{r}2 \\
\text { to } \\
33\end{array}$ & $\begin{array}{rl}0 & 4 \\
\text { to } & \\
6 & 6\end{array}$ & $\begin{array}{r}3 \\
\text { to } \\
22\end{array}$ & $\begin{array}{l}14 \\
\text { to } \\
30\end{array}$ & $\begin{array}{l}06 \\
\text { to } \\
44\end{array}$ & $\begin{array}{ll}6 & 3 \\
\text { to } & \\
13 & 4\end{array}$ & $\begin{array}{l}1 / 10 \\
\text { and } \\
1 / 40\end{array}$ & 45 & 20 \\
\hline $\begin{array}{l}\text { Deeper } \\
\text { waters }\end{array}$ & $\begin{array}{l}40 \\
\text { to } \\
70\end{array}$ & $\begin{array}{ll}8 & 0 \\
\text { to } & \\
14 & 0\end{array}$ & $\begin{array}{l}10 \\
\text { to } \\
25\end{array}$ & $\begin{array}{l}112 \\
\text { to } \\
28\end{array}$ & $\begin{array}{l}20 \\
\text { to } \\
50\end{array}$ & $\begin{array}{ll}5 & 0 \\
\text { to } & \\
13 & 0\end{array}$ & $1 / 100$ & 45 & 20 \\
\hline
\end{tabular}

The rubble-mound was made of quarry stones with dlameters of about $2 \mathrm{~cm}$ to $35 \mathrm{~cm}$ ( $40 \mathrm{~cm}$ to $70 \mathrm{~cm}$ in prototype), and covered with two layers of precast concrete armor blocks such as hollow square, hollow tetrahedron, and $N$-shape blocks with dead weights of 250 grams and 750 grams (2 tons and 6 tons in prototype) The slope of the rubble-mound was kept 115 
as shown in Fig 1 The characteristics of the armor blocks used in the experiments are summerized in Table 3

TABLE 3 CHARACTERISTICS OF ARMOR BLOCKS USED IN EXPERIMENTS

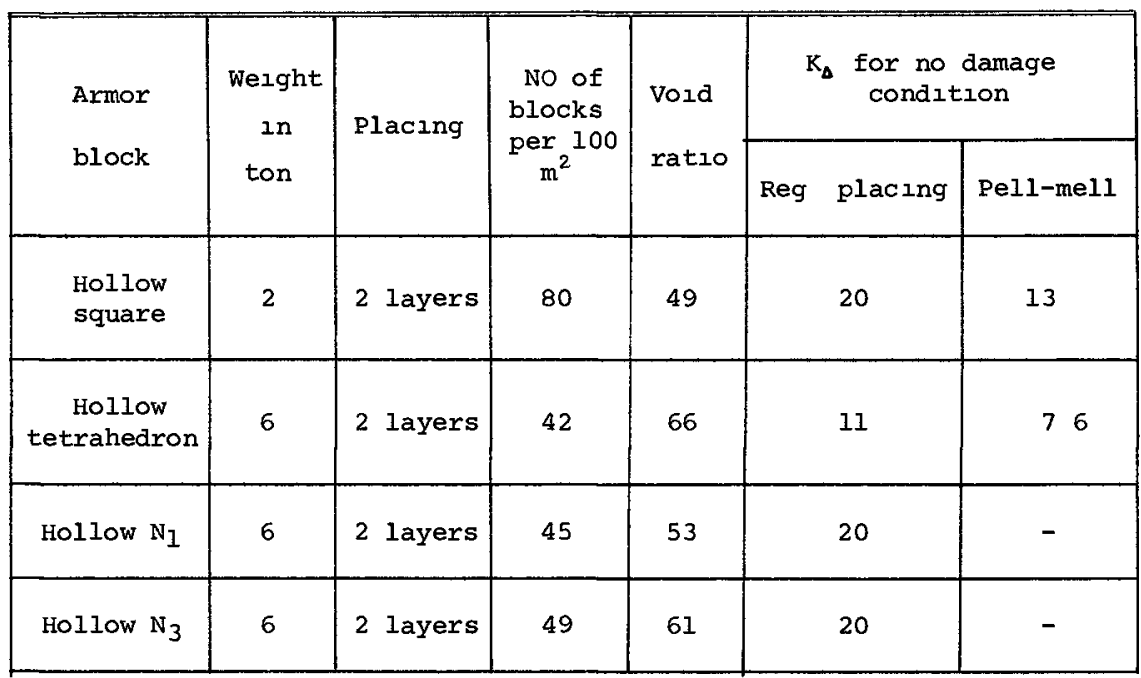

The crown width of the rubble-mound, B, was taken the width required for placing 25 or 3 rows of the armor blocks used, from the experiences in seas of the stability and absorption of wave energy of the armor blocks

\section{EXPERIMENTAL RESULTS}

Effect of Water Depth at the Toe of the Rubble-Mound of the Sea-Wall

The volume of wave overtopping is greatly affected by the point of breaking of the incident wave, whlch can be divided into the following three cases

1 When the incident wave breaks offshore from the toe of the rubblemound This case may be termed "Offshore Breaking", in which the over. topping is the minimum of the three cases

2 When the incldent wave breaks at or near the toe of the rubble-mound This case may be termed "Breaking at Toe" The relative overtopping and relative run-up are the maximum of the three cases as seen in Fig 3 3 When the incident wave breaks on the slope of the rubble-mound Thıs case 15 termed "Breaking on slope" This case occurs when the rubblemound is located in larger depth of water than the depth of breaking of the incident wave 
The effect of $h_{1} / L$ on $q / q_{0}$ is shown in Fig 3 in the cases when the relative crown helghts of the sea-wall and rubble-mound, $\mathrm{H}_{C} / \mathrm{H}$ and $\mathrm{H}_{r} / \mathrm{H}$, as well as the steepness of the Incident wave, $H / L$, are kept constant Fig 3 shows that $q / q_{0}$ is the maximum when the toe of the rubble-mound is located at a little larger depth of water than or near the point of breakıng, 1 e $h_{b}=128 \mathrm{Hb}_{\mathrm{b}}$ whlch $1 \mathrm{~s}$ the breaking depth of solitary wave The reason is attributed to the fact that the point of breaking of the incldent wave somewhat moves toward offshore due to the existence of the rubble-mound

However, when $h_{1} / H \geqq 17$, In whlch the Incldent wave always breaks on the slope of the rubble-mound, the parameters of $h_{1} / H$ and $h_{1} / L$ have little effect of overtopping and run-up The experimental results obtaıned at the Waterways Experıment Station (1) and Coastal Englneerıng Research Center (2) also showed roughly the fact that when the ratio of $h_{1} / H$ is between 218 and 312 or as long as the waves break on the slope of a structure, $h_{1} / H$ had little effect on wave run-up

Effect of the Steepness of the Inczdent Wave

Fig 4 shows the effect of $\mathrm{H} / \mathrm{L}$ of the incident wave on $\mathrm{q} / q_{0}$ when $\mathrm{H}_{\mathrm{C}} / \mathrm{H}, \mathrm{H}_{\mathrm{r}} / \mathrm{H}$, and $\mathrm{h}_{1} / \mathrm{H}$ are kept constant Though the relative overtopping seems the maximum near $H / L$ of about 0.025 , sea-walls in general are designed by the characterıstics of desıgn waves decided from storm conditions at the site

Effect of the Bottom Slope

According to comparisons of the results of the experiments, Figs 5 and 6 , In whlch the bottom slope of 1 he wave channel was changed $1 / 10$ and $1 / 40$, It was noted that the cases of $1=1 / 10$ generally caused larger overtopping than those of $1=1 / 40$, but the effect of the bottom slope on the overtopping was smaller than that of the other parameters

Effects of the Relative Crown Helghts of the Sea-Wall and Rubble-Mound

The effect of the relative crown helght of the sea-wall, $\mathrm{H}_{\mathrm{C}} / \mathrm{H}, \mathrm{Is}$ shown in Figs 7 and 8 for the varlous values of the relative crown helghts of the rubble-mound, $\mathrm{H}_{r} / \mathrm{H}$ It may be seen in Figs 7 and 8 that the value of $\mathrm{H}_{\mathrm{C}} / \mathrm{H}$ must be taken larger than 10 at least in order to be $q /$ qo less than $5 \times 10^{-3}$ which will be the higher limit applicable to the sea-walls Figs $g$ and 10 show the effect of $H_{r} / H$ on $q / q_{0}$ for the scope of $10 \leq \mathrm{H}_{\mathrm{C}} / \mathrm{H}<13$, and also the effect of the bottom slope on $\mathrm{q} / \mathrm{qo}$ It may $\overrightarrow{b e}$ understood in Figs 9 and 10 that in order to be $q /$ qo less than $5 \times 10^{-3}, \mathrm{H}_{r} / \mathrm{H}$ must be taken larger than 07 for the scope of the "Breaking at Toe" and $I=1 / 40$, and $\mathrm{H}_{r} / \mathrm{H}>11$ for the same scope of $1=1 / 10$

Relatıonshıps among $\mathrm{q} / \mathrm{q}_{0}, \mathrm{H}_{\mathrm{C}} / \mathrm{H}$ and $\mathrm{H}_{\mathrm{r}} / \mathrm{H}$ for the Case of "Breakıng on slope"

As has been mentioned, when the value of $h_{1} / H$ exceeds 17 the effect of $h_{1} / H$ or $h_{1} / t$ on $q / q_{o}$ is negliglbly smaller than the other parameters, and in the scope of the "Breaking on slope" the following relationship was found 


$$
\frac{\mathrm{H}_{C}}{\mathrm{H}}+\frac{\mathrm{H}_{\mathrm{r}}}{\mathrm{H}}=\mathrm{C}
$$

in which $\mathrm{C}$ is a constant for a value of $\mathrm{q} / \mathrm{q}_{0}$ and $\mathrm{a}$ kind of armor block used on the slope of the rubble-mound Figs 11 and 12 show the relationships in the scope of $\mathrm{h} / \mathrm{L}=0090$ to 0450 for the various values of $q / q_{0}$ and the two kinds of armor block such as $\mathrm{N}_{1}$ - and $\mathrm{N}_{2}$ - blocks Tables 4 and 5 show the values of $\mathrm{C}$

TABLE 4 VALUES OF $C$ FOR $\mathrm{N}_{1}$-BLOCK

\begin{tabular}{|c|c|c|c|c|}
\hline$q / q_{0}$ & $10^{-4}$ & $10^{-3}$ & $5 \times 10^{-3}$ & $10^{-2}$ \\
\hline$C$ & 25 & 20 & 175 & 16 \\
\hline
\end{tabular}

TABLE 5 VALUES OF $C$ FOR $\mathrm{N}_{3}-\mathrm{BLOCK}$

\begin{tabular}{|c|c|c|c|c|}
\hline $\mathrm{q} / \mathrm{qo}$ & $10^{-4}$ & $10^{-3}$ & $5 \times 10^{-3}$ & $10^{-2}$ \\
\hline $\mathrm{C}$ & 23 & 18 & 155 & 14 \\
\hline
\end{tabular}

\section{Effect of the Permeability of the Rubble-Mound}

It has been well realized that the permeability and the shape of volds of rubble-mounds play a great role of the absorption of waves ruming up the slope of the rubble-mound In order to prove the effect of the permeability and the shape of volds of the rubble-mound on the overtopping of sea-wall, the three kinds of $\mathrm{N}$-shape armor block, shown In Fig 13, which have a same shape but different vold ratioes of 53 per cent for $\mathrm{N}_{1}, 55$ per cent for $\mathrm{N}_{2}$, and 61 per cent for $\mathrm{N}_{3}$, were used as the armor block of the rubble-mound, and tetrahedron blocks which have a different shape of volds and a vold ratio of 66 per cent were also used The experimental results are shown in Fig $14 \quad$ Fig 14 shows that for a same shape of volds of armor layers the capacity to absorb waves increases as the vold ratio increases, but for different shapes of volds of armor layers the capacity to absorb wave energy is not always proportional to the vold ratio 
EFFECT OF RECURVATURE OF A SEA-WAIL AND SIMILARITY ON OVERTOPPING

Taking the origin of the rectangular co-ordinates at the top of the recurvature of a sea-wall, as shown in Fig 15, the x-axls as positlve toward the offshore direction, and the z-axis vertically upward, the equation of motion of a water mass, $m$, exerted by wind force are given by

$$
\begin{aligned}
& m \frac{d^{2} x}{d t^{2}}=-P \quad \ldots \ldots \ldots \ldots \ldots \ldots \ldots \ldots \ldots \ldots \ldots \ldots \ldots \ldots \ldots \ldots \ldots \ldots \ldots \ldots \ldots \ldots \ldots \ldots \ldots \ldots \ldots \ldots \ldots \ldots \ldots \\
& m \frac{d^{2} z}{d t^{2}}=-m g+P_{u} \quad \ldots \ldots \ldots \ldots \ldots \ldots \ldots \ldots
\end{aligned}
$$

In whlch $P$ denotes the horlzontal component of the wind pressure acting from the offshore side, $P_{u}$ is the vertical component of the wind pressure, and $\mathrm{g}$ defines the acceleration of gravity $\mathrm{P}$ is given by

$$
P=\zeta \cdot w_{a} \cdot A \cdot \frac{V^{2}}{2 g}
$$

In whlch $\mathrm{V}$ denotes the wind velocity, A is the area of the water mass exerted by $P, w_{a}=\rho_{a} \cdot g=$ unlt welght of $a l r$, and $\zeta$ defines the coefflclent of drag which is a function of Reynolds number and the shape of the water mass

(1) A water mass of sphere

Iutting the water mass be a sphere with a diameter of $d$, and let us calculate Reynolds number for $d=001$ to $010 \mathrm{~m}$, a wind velocity of 20 meters per second and at temperature of 20 degrees in centigrade

$$
R_{e}=\frac{V d}{V}=133 \times 10^{-4} \text { to } 133 \times 10^{-5}
$$

The drag coefficient is nearly constant for the Reynolds number, $1 e, \zeta=04$ to 05

Taklng $\zeta=05$, and $m=(4 / 3) \rho \pi r^{3}$ in whlch $\rho$ is the density of water, and $r$ is the radius of the water sphere,

$$
\frac{d^{2} x}{d t^{2}}=-\frac{3}{16} \cdot \frac{\rho_{a}}{\rho} \cdot \frac{v^{2}}{r}
$$

Let the velocity of the water mass be $v_{0}$ at $t=0$ and $x=0$, and the angle between the direction and the $x$-axis be $\theta_{0}$,

$$
\frac{d x}{d t}=-\frac{3}{16} \quad \frac{\rho_{a}}{\rho} \cdot \frac{v^{2}}{r} t+v_{0} \cos \theta_{0} \ldots \ldots \ldots \ldots \ldots . .
$$

and

$$
x=-\frac{3}{32} \cdot \frac{\rho_{a}}{\rho} \cdot \frac{v^{2}}{r} t^{2}+v_{0} t \cos \theta_{0}
$$


The time, $t_{0}$, which a water mass spends untll it comes back again on the z-axis after leaving the top, 0 , of the sea-wall, is obtalned from $\mathrm{Eq} 9$

$$
t_{0}=\frac{v_{0} \cos \theta_{0}}{\frac{3}{32} \cdot \frac{\rho a}{\rho} \cdot \frac{v^{2}}{r}}
$$

If $v_{u}$ represents the upward component of wand veloclty at the top of the sea-wall, $P_{u}$ is glven by

$$
\mathrm{P}_{\mathrm{u}}=\zeta \cdot \rho_{\mathrm{a}} \cdot \mathrm{g} \cdot \mathrm{A} \cdot \frac{\mathrm{Vu}^{2}}{2 \mathrm{~g}}=\frac{1}{4} \rho_{\mathrm{a}} \cdot \pi \mathrm{r}^{2} \cdot \mathrm{Vu}^{2}
$$

Assuming $v_{u}=\frac{1}{3} v$,

$$
\mathrm{Pu}_{\mathrm{u}}=\frac{1}{36} \rho_{\mathrm{a}} \cdot \pi \mathrm{r}^{2} \cdot \mathrm{v}^{2}
$$

Substituting Eq 12 into Eq 5,

$$
\frac{d^{2} z}{d t^{2}}=-g+\frac{1}{48} \frac{\rho_{a}}{\rho} \frac{v^{2}}{r}
$$

as

$$
\frac{d z}{d t}=v_{0} \sin \theta_{0}, \text { for } t=0
$$

\section{Integrating}

$$
z=v_{0} t \sin \theta_{0}+\frac{1}{2}\left(-g+\frac{1}{48} \cdot \frac{\rho_{a}}{\rho} \cdot \frac{v^{2}}{r}\right) t^{2}
$$

If the third term of the right hand side of Eq 14 is neglected, since it is approximately 20 per cent of the second term,

$$
z=v_{0} t \sin \theta_{0}-\frac{1}{2} g t^{2}
$$

If $t_{z}$ represents the time whlch a water mass spends untıl it falls agaln onto the $x$-axis by the gravity force after leaving the top of the sea-wall,

$$
t_{z}=\frac{2 v_{0} \sin \theta_{0}}{q}
$$

Denoting by $t$ the time which the water mass spends until it falls down lnto the land over the sea-wall after leaving the top of the seawal1,

$$
t_{z} \geqq t>t_{0}
$$


The values of $t_{0}, t_{z}$, and $(1 / 2) t_{0} v_{0} \cos \theta_{0}$, whlch represents the horizontal flying distance of the water mass in the time of $t_{0}$ are tabulated in Table 6 for $\mathrm{V}=10,15$ and $20 \mathrm{~m} / \mathrm{sec}, \mathrm{V}_{0}=4$ meters per second, $r=05,10$ and $50 \mathrm{~cm}$, and $\theta_{0}=50^{\circ}$ and $60^{\circ}$

TABLE 6 VALUES OF $t_{0}, t_{z}$, and $\left.\frac{1}{2} t_{0} v_{0} \cos \theta_{0}\left(\rho_{a} \chi \rho=1 / 827\right)\right)$

\begin{tabular}{|c|c|c|c|c|c|c|c|c|c|c|}
\hline \multirow{2}{*}{$\begin{array}{c}\mathrm{V} \\
(\mathrm{m} / \mathrm{sec})\end{array}$} & \multirow[b]{2}{*}{$\theta_{0}$} & \multicolumn{3}{|c|}{$r=05 \mathrm{~cm}$} & \multicolumn{3}{|c|}{$r=1 \mathrm{~cm}$} & \multicolumn{3}{|c|}{$r=5 \mathrm{~cm}$} \\
\hline & & $\begin{array}{c}t_{0} \\
\text { (sec) }\end{array}$ & $\begin{array}{c}t_{z} \\
\text { (sec) }\end{array}$ & $\begin{array}{c}\frac{1}{2} t_{0} v_{0} \\
x \cos \theta_{0} \\
(m)\end{array}$ & $\begin{array}{c}t_{0} \\
(\sec )\end{array}$ & $\begin{array}{c}t_{z} \\
(s e c)\end{array}$ & $\begin{array}{c}\frac{1}{2} t_{0} v_{0} \\
x \cos \theta_{0} \\
\text { (m) }\end{array}$ & $\begin{array}{c}t_{0} \\
(\mathrm{sec})\end{array}$ & $\begin{array}{c}t_{0} \\
(\mathrm{sec})\end{array}$ & $\begin{array}{c}\frac{1}{2} t_{0} v_{0} \\
x \cos \theta_{0} \\
(\mathrm{~m})\end{array}$ \\
\hline 10 & $\begin{array}{l}50^{\circ} \\
60\end{array}$ & $\mid \begin{array}{ll}1 & 14 \\
0 & 88\end{array}$ & $\begin{array}{ll}0 & 63 \\
0 & 71\end{array}$ & $\begin{array}{ll}1 & 47 \\
0 & 88\end{array}$ & $\begin{array}{ll}2 & 27 \\
1 & 76\end{array}$ & $\begin{array}{ll}0 & 63 \\
0 & 71\end{array}$ & $\begin{array}{ll}2 & 93 \\
1 & 76\end{array}$ & $\begin{array}{rl}11 & 4 \\
8 & 80\end{array}$ & $\begin{array}{ll}0 & 63 \\
0 & 71\end{array}$ & $\begin{array}{rl}14 & 7 \\
8 & 80\end{array}$ \\
\hline 15 & $\begin{array}{l}50 \\
60\end{array}$ & $\mid \begin{array}{ll}0 & 50 \\
0 & 39\end{array}$ & $\begin{array}{ll}0 & 63 \\
0 & 71\end{array}$ & $\begin{array}{ll}0 & 65 \\
0 & 39\end{array}$ & $\begin{array}{ll}1 & 01 \\
0 & 78\end{array}$ & $\begin{array}{ll}0 & 63 \\
0 & 71\end{array}$ & $\begin{array}{ll}1 & 30 \\
0 & 78\end{array}$ & $\begin{array}{ll}5 & 04 \\
3 & 92\end{array}$ & $\begin{array}{ll}0 & 63 \\
0 & 71\end{array}$ & $\begin{array}{ll}6 & 48 \\
3 & 92\end{array}$ \\
\hline 20 & $\begin{array}{l}50 \\
60\end{array}$ & $\mid \begin{array}{ll}0 & 28 \\
0 & 22\end{array}$ & $\begin{array}{ll}0 & 63 \\
0 & 71\end{array}$ & $\begin{array}{ll}0 & 36 \\
0 & 22\end{array}$ & $\begin{array}{ll}0 & 57 \\
0 & 44\end{array}$ & $\begin{array}{ll}0 & 63 \\
0 & 71\end{array}$ & $\begin{array}{ll}0 & 72 \\
0 & 44\end{array}$ & $\begin{array}{ll}2 & 85 \\
2 & 20\end{array}$ & $\begin{array}{l}0.63 \\
0.71\end{array}$ & $\begin{array}{ll}3 & 68 \\
2 & 20\end{array}$ \\
\hline
\end{tabular}

Since $t_{0}$ is larger than $t_{z}$ in the scope surrounded by a thick line, the water mass does not jump into the land over the sea-wall This means that if the water mass is assumed a sphere with a diameter of $d$, the water mass with $d \leq 1 \mathrm{~cm}$ wlll jump into the land over the sea-wall when $\mathrm{y} \geq 15 \mathrm{~m} / \mathrm{sec}$, the water mass w1th $\mathrm{d} \leqq 2 \mathrm{~cm}$ will jump into the land when $\mathrm{y} \geq 20 \mathrm{~m} / \mathrm{sec}$

(2) A wall of water

Let us consider that the water spray over the top of the sea-wall is a wall of water with a thickness of $b$ since the drag coefficient of the water wall is taken $\zeta=2$ for Reynolds numbers $\operatorname{Re}=5 \times 10^{3}$ to $10^{6}$, the horizontal component of the wind pressure per unit area is

$$
\mathrm{P}=\rho_{\mathrm{a}} \cdot \mathrm{V}^{2}
$$

Since $m=\rho \cdot b, E q \quad 4$ may be written

$$
\frac{d^{2} x}{d t^{2}}=-\frac{\rho_{a}}{\rho} \cdot \frac{v^{2}}{b}
$$


Using the boundary condltions $d x / d t=v_{0} \cos \theta_{0}$ and $x=0$ for $t=0$, $x=-\frac{1}{2} \cdot \frac{\rho_{a}}{\rho} \cdot \frac{v^{2}}{b} t^{2}+v_{0} t \cos \theta_{0}$

$t=t_{0}$ for $x=0$ Is given by

$$
t_{0}=\frac{v_{0} \cos \theta_{0}}{\frac{1}{2} \cdot \frac{\rho_{a}}{\rho}: \frac{v^{2}}{b}}
$$

If $P_{u}$ is neglected, $t_{z}$ is given by Eq 16 As previously mentioned, only when the condition $t_{z} \geqq t>t_{0}$ is satisfied, the water wall can fall Into the land over the sea-wall Table 7 is shown the values of $t_{0}, t_{z}$, and $(1 / 2)$ tovo $\cos \theta_{0}$

TABLE 7 VALUES OF $t_{0}, t_{z}$, and $\frac{1}{2} t_{o} v_{0} \cos \theta_{0}$

\begin{tabular}{|c|c|c|c|c|c|c|c|c|c|c|}
\hline \multirow{2}{*}{$\begin{array}{c}V \\
(m / s e c)\end{array}$} & \multirow[b]{2}{*}{$\theta_{0}$} & \multicolumn{3}{|c|}{$\mathrm{b}=1 \mathrm{~cm}$} & \multicolumn{3}{|c|}{$\mathrm{b}=5 \mathrm{~cm}$} & \multicolumn{3}{|c|}{$\mathrm{b}=10 \mathrm{~cm}$} \\
\hline & & $\begin{array}{c}t_{0} \\
(\mathrm{sec})\end{array}$ & $\begin{array}{c}t_{z} \\
\text { (sec) }\end{array}$ & $\begin{array}{l}\frac{1}{2} t_{0} v_{0} \\
x_{\cos \theta_{0}} \\
\text { (m) }\end{array}$ & $\begin{array}{c}t_{0} \\
(\mathrm{sec})\end{array}$ & $\begin{array}{c}t_{z} \\
\text { (sec) }\end{array}$ & $\begin{array}{c}\frac{1}{2} t_{0} v_{0} \\
x_{\cos \theta_{0}} \\
(m)\end{array}$ & $\begin{array}{c}t_{0} \\
(\sec )\end{array}$ & $\left\{\begin{array}{c}\tau_{z} \\
(\mathrm{sec})\end{array}\right.$ & $\begin{array}{c}\frac{1}{2} t_{0} v_{0} \\
\cos \theta_{0} \\
(m)\end{array}$ \\
\hline 10 & $\begin{array}{l}50^{\circ} \\
60\end{array}$ & $\begin{array}{ll}0 & 43 \\
0 & 33\end{array}$ & $\begin{array}{ll}0 & 63 \\
0 & 71\end{array}$ & $\begin{array}{ll}0 & 55 \\
0 & 33\end{array}$ & $\begin{array}{ll}2 & 13 \\
1 & 65\end{array}$ & $\begin{array}{ll}0 & 63 \\
0 & 71\end{array}$ & $\begin{array}{ll}2 & 88 \\
1 & 65\end{array}$ & $\begin{array}{ll}4 & 25 \\
3 & 31\end{array}$ & $\begin{array}{ll}0 & 63 \\
0 & 71\end{array}$ & $\begin{array}{ll}5 & 46 \\
3 & 31\end{array}$ \\
\hline 15 & $\begin{array}{l}50 \\
60\end{array}$ & $\begin{array}{ll}0 & 19 \\
0 & 15\end{array}$ & $\begin{array}{ll}0 & 63 \\
0 & 71\end{array}$ & $\begin{array}{ll}\text { o } & 24 \\
\text { o } & 15\end{array}$ & $\begin{array}{ll}0 & 95 \\
0 & 74\end{array}$ & $\begin{array}{ll}0 & 63 \\
0 & 71\end{array}$ & $\begin{array}{ll}1 & 22 \\
0 & 74\end{array}$ & $\begin{array}{ll}1 & 89 \\
1 & 47\end{array}$ & $\begin{array}{ll}0 & 63 \\
0 & 71\end{array}$ & $\begin{array}{ll}2 & 43 \\
1 & 47\end{array}$ \\
\hline 20 & $\begin{array}{l}50 \\
60\end{array}$ & $\begin{array}{ll}0 & 11 \\
0 & 08\end{array}$ & $\begin{array}{ll}0 & 63 \\
0 & 71\end{array}$ & $\begin{array}{ll}0 & 14 \\
0 & 08\end{array}$ & $\begin{array}{ll}0 & 53 \\
0 & 41\end{array}$ & $\begin{array}{ll}0 & 63 \\
0 & 71\end{array}$ & $\begin{array}{ll}0 & 68 \\
0 & 41\end{array}$ & $\begin{array}{ll}1 & 06 \\
0 & 83\end{array}$ & $\begin{array}{ll}0 & 63 \\
0 & 71\end{array}$ & $\begin{array}{ll}1 & 36 \\
0 & 83\end{array}$ \\
\hline
\end{tabular}

In Table 7 the scope enclosed by a thick line shows the cases of $t_{0}>t_{z}$ According to Table 7, It may be known that a wall of overtopping with a thicknessof one $\mathrm{cm}$ is blown down within one second into the land over the sea-wall by winds with veloclties equal to or larger than $10 \mathrm{~m} / \mathrm{sec}$, and a wall of overtopping with a thickness of $5 \mathrm{~cm}$ by winds with velocities equal to or larger than $20 \mathrm{~m} / \mathrm{sec}$ 
Similarity on Overtopping

(1) A water mass of sphere

Let us consider of a water mass of sphere with a diameter $d$ overtopping a sea-wall Assuming $d_{p}$, the diameter in prototype, is $3 \mathrm{~cm}$ to $10 \mathrm{~cm}, d_{m}$, the diameter in model, the scale of which is 120 to prototype, is 15 to $5 \mathrm{~mm}$ $\mathrm{m} / \mathrm{sec} 1 \mathrm{~s}$

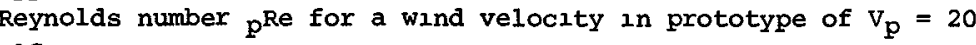

$$
p^{R e}=\frac{V_{p} \cdot d_{p}}{v}=40 \times 10^{4} \text { to } 133 \times 10^{5}
$$

In the model

$$
\mathrm{m}^{\mathrm{Re}}=\frac{\mathrm{Vm} \cdot \mathrm{dm}}{\nu}=45 \times 10^{2} \text { to } 147 \times 10^{3}
$$

Drag coefficlents for the spheres are

$$
\zeta_{p} \neq \sim 045 \text { to } 05 \text { in prototype, }
$$

and

$$
\zeta_{p}=\sim 060 \text { to } 045 \text { in model, }
$$

thus, it may be assumed approximately $\zeta_{\mathrm{p}}=\zeta_{\mathrm{m}}$

This means that if a mass of water overtopping a sea-wall is a sphere with a dlameter $d \geqq 3 \mathrm{~cm}$, the motion of the water mass exerted by a wind of $v_{p}=20 \mathrm{~m} / \mathrm{sec}$ may be stated to be approximately followed by Froude law of similarity, 1 e the results of the model experiment may be stated to ne approximately similar to the results of the nature However, if the dlameter of the water mass, $d_{p}$, is smaller than about $3 \mathrm{~cm}, \zeta_{\mathrm{p}}=\sim 04$ to 05 for $\mathrm{p}$ Re $=\sim 10^{4}$, as against $\zeta_{\mathrm{m}}=\sim 06$ to

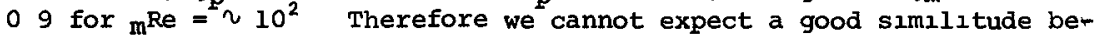
tween model and prototype But from a practical point of view on the water quantıty of wave overtopping, the volume of such spray of water would be consıdered to be neglı'glble small

(2) A wall of water

Let us consider the overtopping as a wall of water This may be the case when large overtopping 15 seen in prototype and model, as seen in Figs 17, 18 and 19, therefore, this case would be the most important in wave overtopping over sea-walls

If the overtopping of wave is assumed as a wall of water, the drag coefficlent of the wall, $\zeta$, is constantly two for all Reynolds numbers larger than $10^{2}$ It, therefore, may be stated that the results of experiments conducted by Froude law are similar to the results in the nature Field observations of overtopping at sea-walls during typhoons have proved that this assumption is correct

It may be concluded from the theoretical considerations described above that the recurvature of a sea-wall would have little effect on wave overtopping when wind velocity exceeds about $15 \mathrm{~m} / \mathrm{sec}$ 


\section{APPLICATION TO DESIGN OF SEA-WALLS AND VERIFICATION BY TYPHOONS}

The results studied in our laboratory have been applied to the design of sea-walls in Japan since 1960 and those sea-walls have been tested by severe typhoons All of the sea-walls whlch have ungone the natural tests have proved that the desıgns were satısfactory and there were generally a falrly good agreement between the experıments and prototypes Some examples are presented herein

(1) Sea-wall in the Port of Wakayama

This sea-wall was constructed in 1958 at a water depth of $7 \mathrm{~m}$ to $8 \mathrm{~m}$ below the Datum IIne offshore a long sandy beach exposed to an open sea in the North Harbor of the Port of Wakayama, Wakayama Prefecture, which is one of the biggest industrial harbors for steel firms in Japan This was the first big sea-wall that harbor eng to protect a reclaimed industrial land located offshore from wave overtopping Fig 16 shows a cross-section of the sea-wall

After completion it was severely hit three times consecutively in September of 1959, 1960 and 1961 Figs 17 and 18 show huge overtoppings of waves whlch were taken when the typhoon was located still far offshore from the harbor

After calculations and experiments, it was recommended that the seawall should have a rubble-mound covered with precast concrete armors in front of the wall and a large drainage channel with a width of $20 \mathrm{~m}$ at the land-side of the sea-wall, as shown in Fig 19

(2) Another Sea-Wall in the Port of Wakayama

The sea-wall, the cross-section of which is shown in Fig 20, was constructed in 1965 and 1966 to protect the industrial area of $18 \mathrm{mill}$ ion $\mathrm{m}^{2}$ reclaimed at the northern part of the Wakayama North Harbor

(a) When the helght and period of the desıgn wave are taken $H_{p}=50 \mathrm{~m}$ and $T_{p}=90$ sec

Since $h_{1} / H=874 / 5=175>17$, thls case 1 s "Breaking on slope" For $\mathrm{H}_{\mathrm{C}} / \mathrm{H}=476 / 5=095=\sim 10$ and $\mathrm{H}_{r} / \mathrm{H}=376 / 5=075$, we obtain $q / q_{0}=5 \times 10^{-3}$ from $F 1 g \quad 11$

(b) When $\mathrm{H}_{\mathrm{p}}=55 \mathrm{~m}$ and $\mathrm{T}_{\mathrm{p}}=130 \mathrm{sec}$

Since $H / L=0041$ and $h_{1} / L=0065$, this case is on the critical condition between "Breaking at Toe" and "Breaking on slope" Using $H_{C} / H=087$ and $H_{r} / H=376 / 55=068$, we obtain $q / q_{0}=5 \times$ $10^{-3}$ for "Breakıng at Toe", and from Fig $11 q / q_{0}=8 \times 10^{-3}$ for "BreakIng on slope", whlch necessitate a large drainage channel as shown in F1g 20

Decision of the Width and Depth of the Dralnage Channel

The design conditions of the drainage channel

$\Delta z=$ helght from the bottom of the dralnage channel to the $x$-axis

$=(D \mathrm{~L}+670 \mathrm{~m})-(\mathrm{DL}+400 \mathrm{~m})=270 \mathrm{~m}$

$\theta_{0}=$ angle of the parapet wall to the $x$-axis $=70^{\circ}$,

$\mathrm{V}=$ wind velocity $=20 \mathrm{~m} / \mathrm{sec}$,

The wave run-ups, $R_{u}$, for the desıgn waves with helghts of $50 \mathrm{~m}$ and $55 \mathrm{~m}$ and periods of $9 \mathrm{sec}$ and $13 \mathrm{sec}$, respectively, were approximately $12 \mathrm{H}$ according to the experiments carried out by using the model of the sea-wall shown in Fig 21 
Let us consider about the design wave with a helght of $5 \mathrm{~m}$ and a period of $9 \mathrm{sec}$, and take the design sea level $\mathrm{D} \mathrm{L}+224 \mathrm{~m}$ The velocity of a water mass of sphere with a dlameter of d at the origin of the co-ordinates, 0 , is obtained by $v_{O}=\sqrt{2 \times 98(60-446)}=55 \mathrm{~m} / \mathrm{sec}$

$t_{z}$ whlch denotes the time that the water mass spends until it falls down on the bottom of the dralnage channel over the sea-wall after leaving the origin 0 is given by

$$
t_{z}=\frac{v_{0} \sin \theta_{0}+\sqrt{v_{0}^{2} \sin ^{2} \theta_{0}+2 g \Delta z}}{g}
$$

By substitution of Eq 22 into $\mathrm{Eq} 9$, the horizontal distance $1_{\mathbf{X}}$ whlch the water mass reaches at the time $t_{z}$ from the origin 0 onto the channel bottom is obtained by

$$
l_{x}=\frac{3}{32} \cdot \frac{\rho_{a}}{\rho} \cdot \frac{v^{2}}{r} t_{z}-v_{o} t \cos \theta_{0} \quad, \ldots . \ldots \ldots \ldots \ldots
$$

From Eqs 22 and $23 t_{z}=144 \mathrm{sec}$ and $1_{x}=160 \mathrm{~m}$ for $\mathrm{d}=001 \mathrm{~m}, 1_{x}=$ $67 \mathrm{~m}$ for $\mathrm{d}=002 \mathrm{~m}$

Consldering a wall of water with a thickness of $b$, the horizontal distance $l_{x}$ is obtalned by substitution of $\mathrm{Eq} 22$ into $\mathrm{Eq} 20, l_{x}=$ $474 \mathrm{~m}$ for $\mathrm{b}=001 \mathrm{~m}, 1_{\mathrm{x}}=224 \mathrm{~m}$ for $\mathrm{b}=002 \mathrm{~m}, 1_{\mathrm{x}}=140 \mathrm{~m}$ for $\mathrm{b}=$ $003 \mathrm{~m}$, and $l_{x}=98 \mathrm{~m}$ for $\mathrm{b}=004 \mathrm{~m}$

The locl of those walls of water are shown in Fig 21 According to Fig 21, if the side wall with a helght of $2 \mathrm{~m}$ from the bottom of the channel is constructed at a distance of $l_{x}=175 \mathrm{~m}$ from the origin 0 , the walls of water with thlcknesses of more than $b=2 \mathrm{~cm}$ and the spheres of water with diameters more than one $\mathrm{cm}$ could be taken into the drainage channel

The length of the sea-wall over which the design wave overtops simultaneously was decided about $350 \mathrm{~m}$ by the experiments, and the factor of safety for the maximum relative overtopping was taken two, therefore the maximum discharge of water for the drainage channel, Qmax, was

$$
\begin{aligned}
& \mathrm{q}=8 \times 10^{-3} \mathrm{q}_{0}=8 \times 10^{-3} \times 5 \times 88 / 2 \pi=056 \mathrm{~m}^{3} / 9 \mathrm{sec} / \mathrm{m} \\
& Q_{\max }=2 \mathrm{q} \times 350=393 \mathrm{~m}^{3} / 9 \mathrm{sec} \\
& =437 \mathrm{~m}^{3} / \mathrm{sec}=\sim 45 \mathrm{~m}^{3} / \mathrm{sec}
\end{aligned}
$$

If the slope of the channel bottom is taken $1 / 1000$, the width $20 \mathrm{~m}$, and the depth $2 \mathrm{~m}$, the channel can discharge $Q_{\max }$ safely

After completion of the drainage channel, the sea-wall has undergone severe typhoons several times, and it has been reported due to the visual observations during the typhoons that the behaviors of the overtopping were quite similar to those of the experiments and almost all overtoppings were assembled into the channels and flowed down safely into the harbor basin

(3) Sea-Wall of the Kansal Electric Power Co Ltd

The sea-wall was constructed in an open sea with a water depth of D I $-250 \mathrm{~m}$ to $300 \mathrm{~m}$ to protect a reclalmed land of about 38 acres whlch was used for an electric power plant of the Kansal Electric Power Co Ltd The sea-wall was requested to be designed no-overtopping even 
during the heaviest typhoon ever experienced there After the calculations shown here and model experiments carrıed out on a scale of 120 in the wave channel shown in Fig 2, the sea-wall shown in Figs 22 and 23 was designed

\section{Estimation of the Overtopping during the Heaviest Typhoon}

The signiflcant wave helght and period of the design wave were taken $\mathrm{H}_{1 / 3}=250 \mathrm{~m}$, and $\mathrm{T}_{1 / 3}=63 \mathrm{sec}$ The hlghest hlgh tide averaged for two hours including the highest tide ever recorded in the harbor was estimated $D L+380 \mathrm{~m}$ Since $h_{1} / H=580 / 25=23>17$, the case $2 \mathrm{~s}$ "Breaking on Slope" Using $\mathrm{H}_{\mathrm{C}} / \mathrm{H}=395 / 250=158$ and $\mathrm{H}_{\mathrm{r}} / \mathrm{H}=175 / 25$ $=070$, we obtain from $F 1 g$ s 11 and $12, q / q_{0}=5 \times 10^{-4}$ and $2 \times 10^{-4}$, respectively

Since the tetrahedron blocks of two tons were used as the armor block of the rubble-mound, $q / q_{0}$ is estimated approximately $3 \times 10^{-4}$ from Fig 14 According to the experiments in which two high tides of $D$ I + $380 \mathrm{~m}$ and $\mathrm{D} \mathrm{I}+330 \mathrm{~m}$ were used and the wind velocity used was always $20 \mathrm{~m} / \mathrm{sec}$, a few overtopping was seen for a tide of $\mathrm{D} \mathrm{L}+380 \mathrm{~m}$ and only a few spray was observed for a $t$ lde of $D \mathrm{~L}+330 \mathrm{~m}$

Shortly after the completion of the sea-wall, it was hit by one of the most severe typhoons ever observed in the harbor, the second Muroto typhoon, whlch passed near over the location of the sea-wall on september 16, 1961 The highest tide during the typhoon was D L $+400 \mathrm{~m}$ and the average highest high tide for two hours was estimated approximately $D$ I $+360 \mathrm{~m}$ The maximum wave helght was assumed $250 \mathrm{~m}$ or $3 \mathrm{Om}$, and strong winds of from $20 \mathrm{~m} / \mathrm{sec}$ to $35 \mathrm{~m} / \mathrm{sec}$ blew from offshore for about $3 \mathrm{hr}$ Pictures taken with the 8-mm movie camera near the top of the seawall during the typhoon showed that comparatively small volume of wave overtopping occursed sometimes over the top of the rubble-mound covered with the two layers of the hollow tetrahedron armors However, there was no overtopping over the top of the sea-wall, as seen in Fig 23 It was proved that there was a good agreement between the experiment and prototype

\section{APPENDIX - REFERENCES}

1 "Wave Run-up and overtopping, Levee Sectıons, Lake Okeechobee, Florlda", Corps of Engrs, Waterways Experıment sta, Tech Report NO 2-449, January, 1959

2 Savılle, Thorndıke, "Wave Run-up on Shore Structures", Proc ASCE, Vol 82, No WW2, April, 1956 


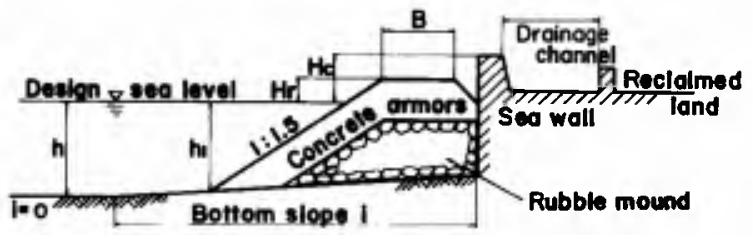

FIG. 1. - CROSS-SECTIONS TYPICAL TYPES OF SEAWALL IN JAPAN UPPER SECTION USED IN DEEPER WATERS LOWER SECTION USED IN SHALLOW BEACH
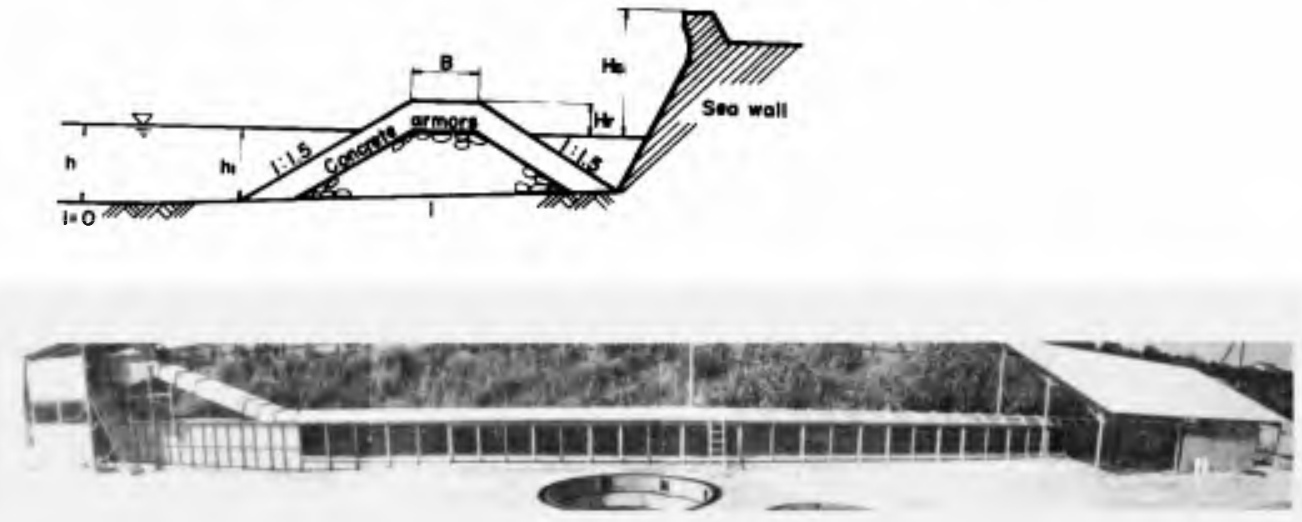

FIG. 2. - WAVE CHANNEL WITH A WIND BLOWER

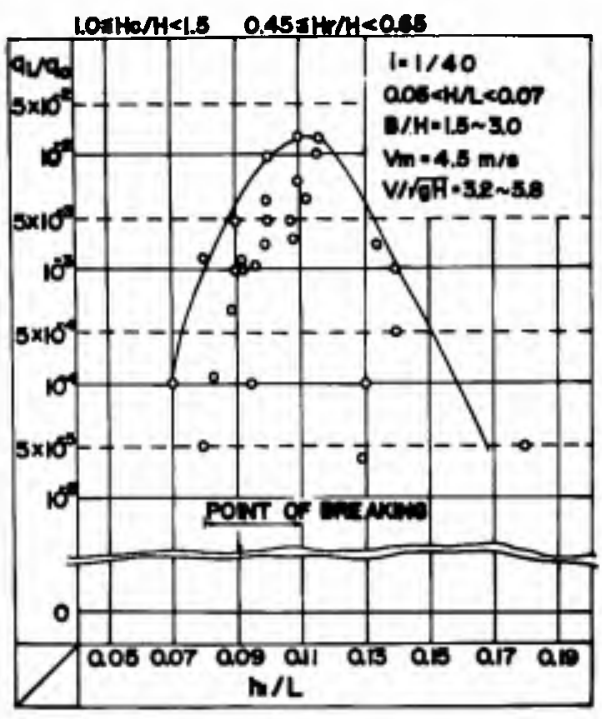

FIG. 3. - RELATIONSHIP BETWEEN RELATIVE OVERTOPPING AND $h_{1} / L$

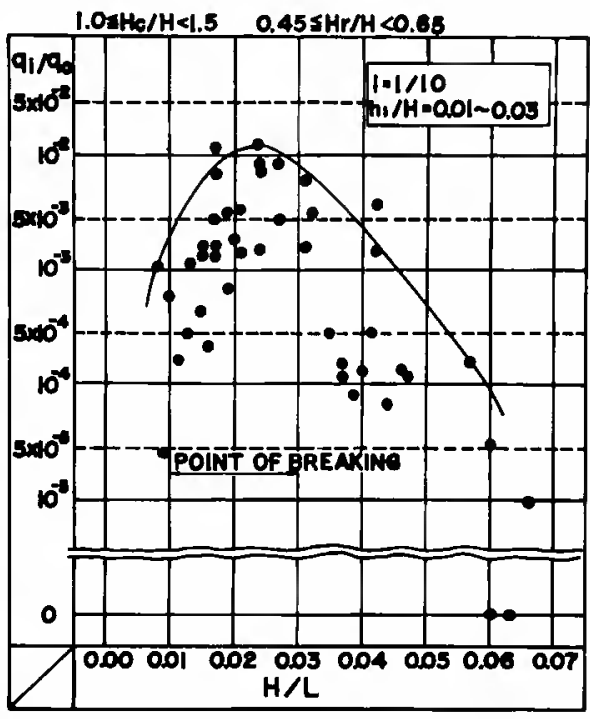

FIG. 4. - RELATIONSHIP BETWEEN $q / q_{0}$ AND $\mathrm{H} / \mathrm{L}$ 


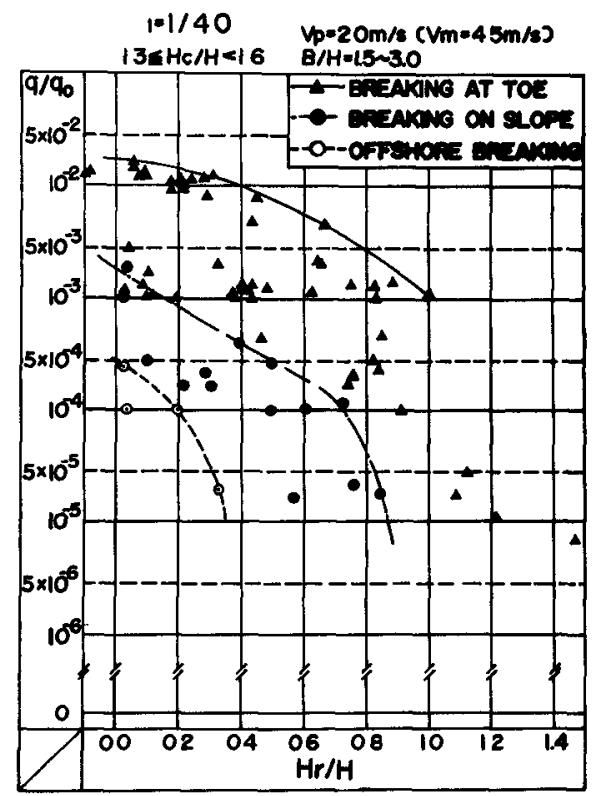

FIG 5 - RELATIONSHIP BETWEEN $q / q_{0}$ AND $H_{x} / H, I=1 / 40$

$1 * 1 / 40$ B/Hil 5 3O V/NA-3.2 58

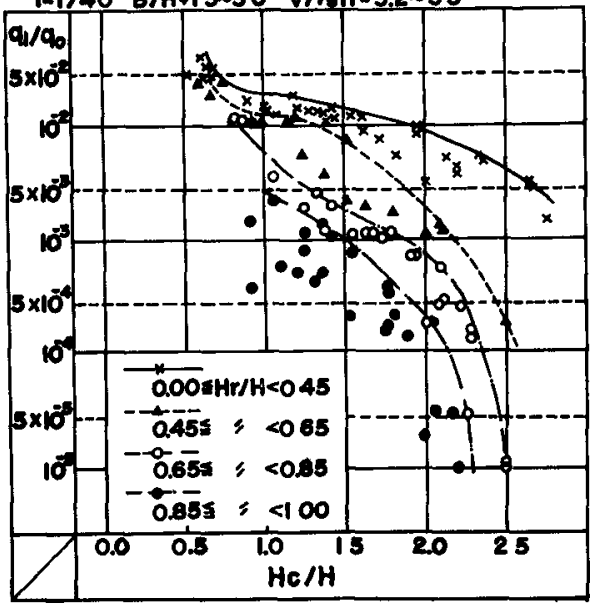

FIG 7 - RELATIONSHIP AMONG $q / q_{0}, \mathrm{H}_{\mathrm{C}} / \mathrm{H}$ AND $\mathrm{H}_{\Upsilon} / \mathrm{H}$

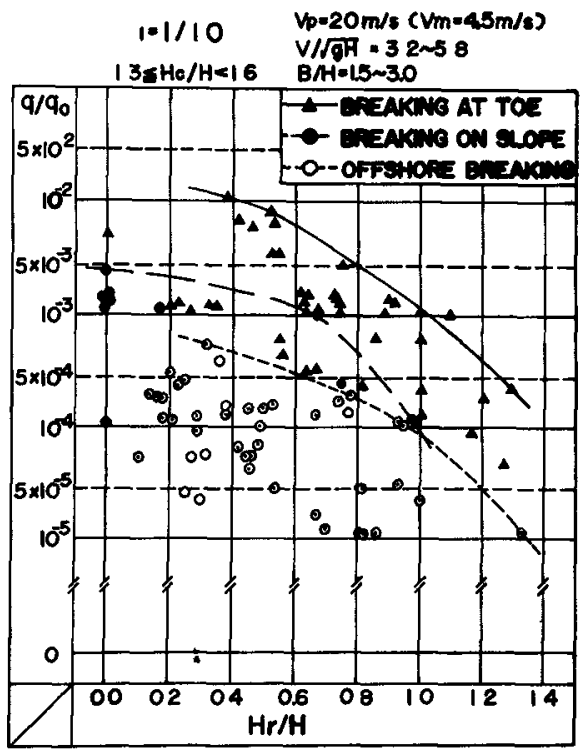

FIG 6 - RELATIONSHIP BETWEEN $q / q_{0}$ AND $H_{K} / H, l=1 / 10$

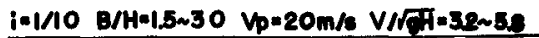

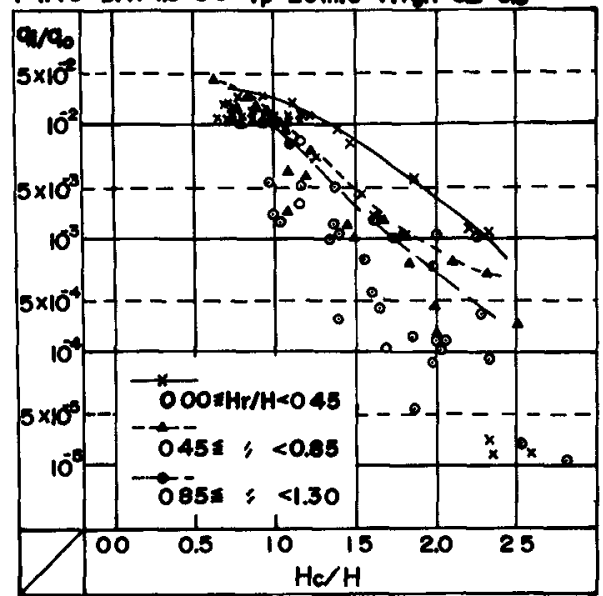

FIG 8 - RELATIONSHIP AMONG $q / q_{O}, H_{C} \mathrm{H}$ AND $\mathrm{H}_{\boldsymbol{x}} / \mathrm{H}$ 


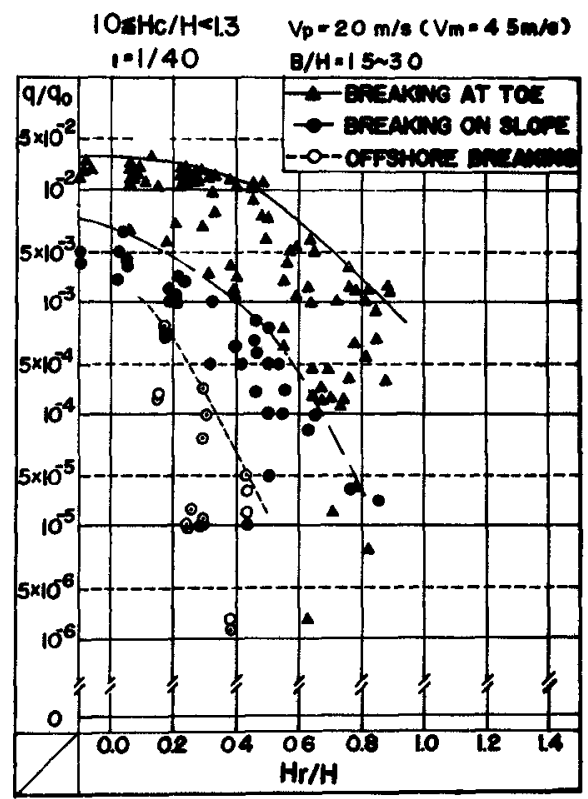

FIG 9 - RELATIONSHIP BETWEEN $\mathrm{q} / \mathrm{q}_{\mathrm{O}}$ AND $\mathrm{H}_{\mathrm{r}} / \mathrm{H}, \mathrm{I}=1 / 40$

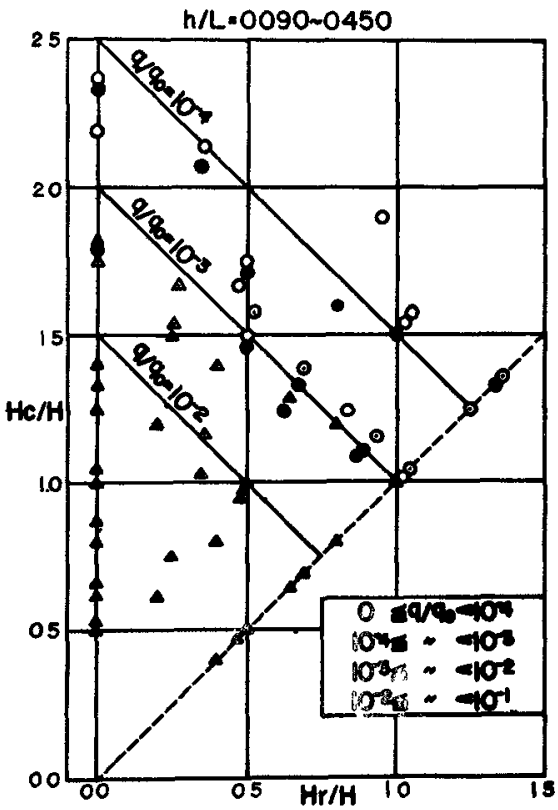

FIG 11 - RELATIONSHIP AMONG $q / q_{0}$, $\mathrm{H}_{\mathrm{C}} / \mathrm{H}$, AND $\mathrm{H}_{\mathrm{r}} / \mathrm{H}$ FOR $\mathrm{N}_{1}-\mathrm{BLOCK}$
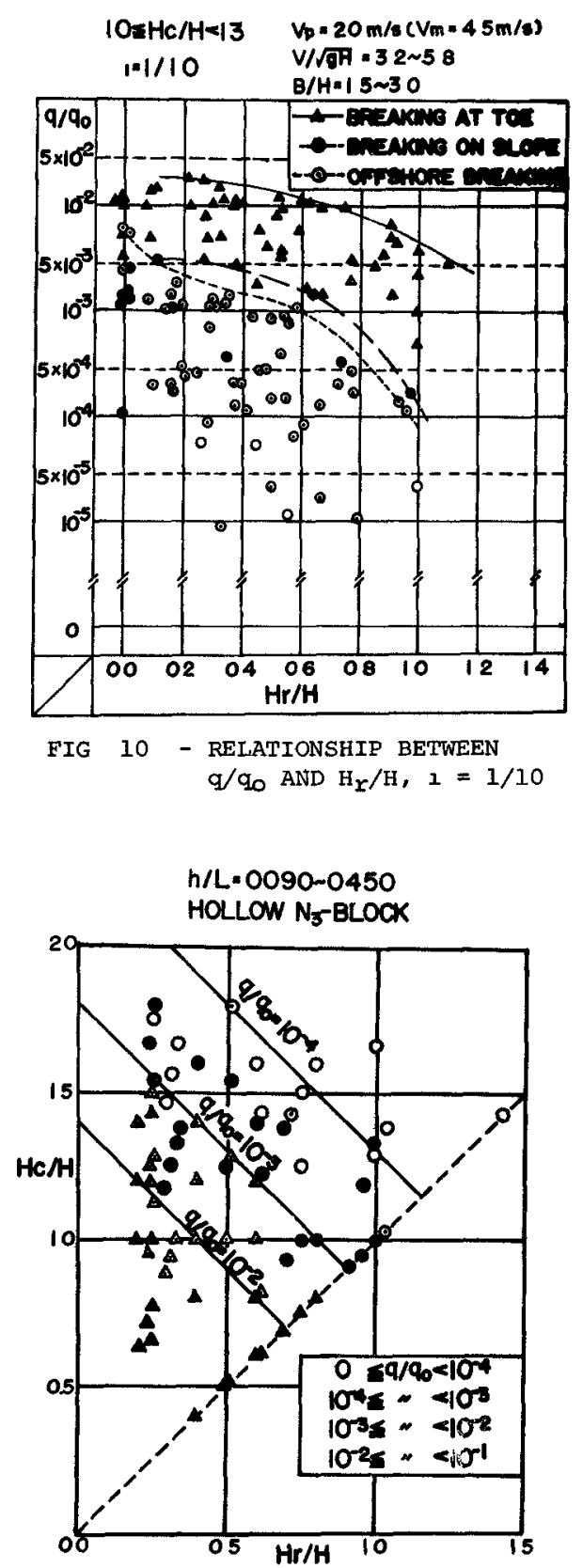

FIG 12 - RELATIONSHIP AMONG $q / q_{0}$, $\mathrm{H}_{\mathrm{C}} / \mathrm{H}$, AND $\mathrm{H}_{r} / \mathrm{H}$ FOR $\mathrm{N}_{3}$-BLOCK 


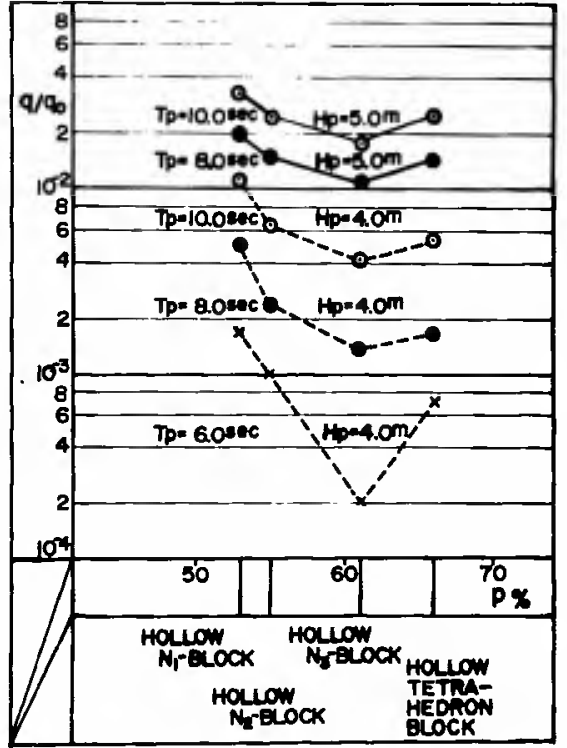

FIG. 14. - RELATIONSHIPS BETWEEN $q / q_{0}$ AND THE VOID RATIO AND SHAPE OF VOID OF ARMOR LAYORS

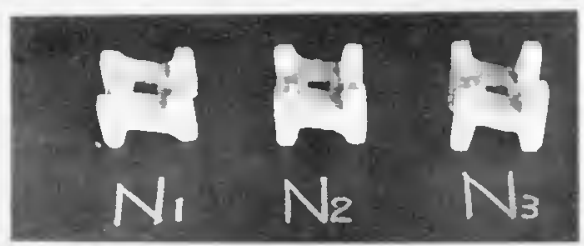

FIG. 13. - HOLLOW N-BLOCK

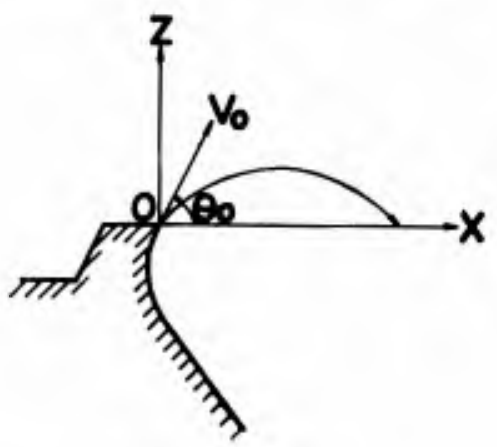

FIG. 15

SEAWARD SIDD

$\nabla=8.4-00000000$

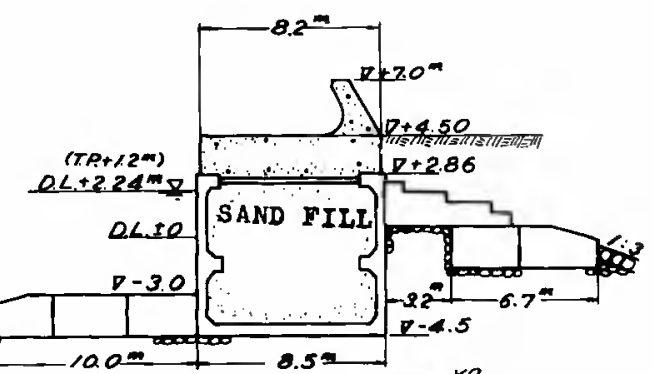

RUBBLE-MOUND $20-60^{\mathrm{Kg}}$

FIG. 16. - CROSS-SECTION OF THE SEA-WALL IN WAKAYAMA HARBOR BEFORE 1961

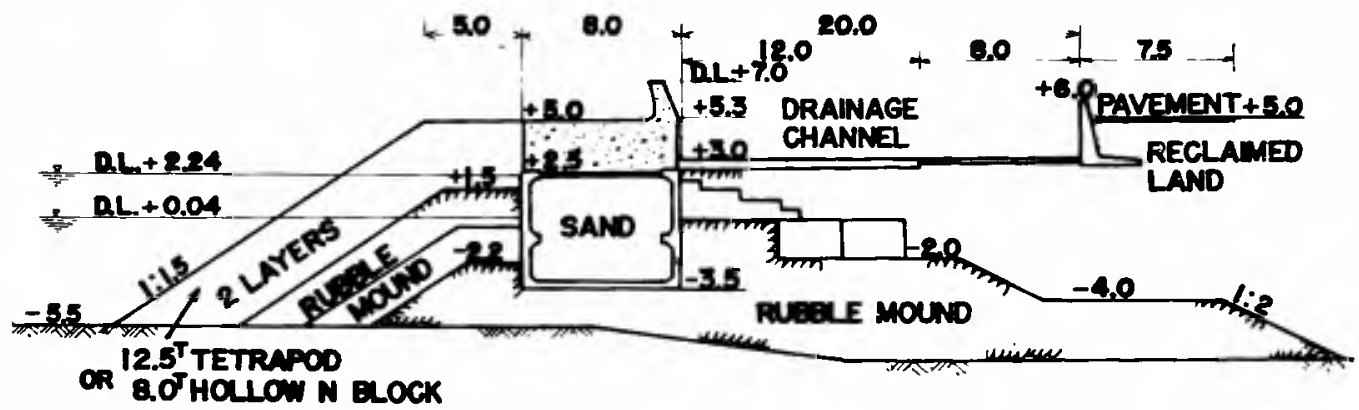

FIG. 19. - CROSS-SECTION OF THE SEA-WALL IMPROVED AFTER THE EXPERIMENTS 


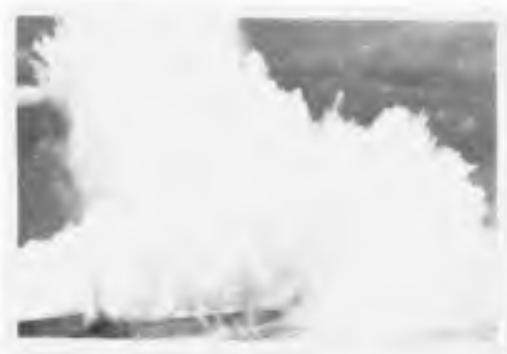

FIG. 17. - LARGE WAVE OVERTOPPINGS AT SEA-WALLS OF WAKAYAMA HARBOR

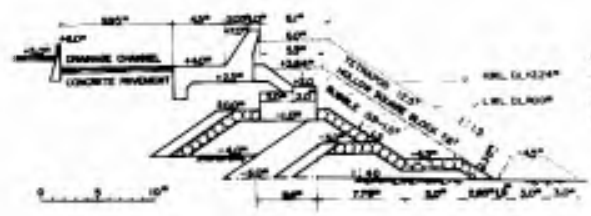

FIG. 20. - CROSS-SECTION OF THE SEAWALI IN WAKAYAMA HARBOR

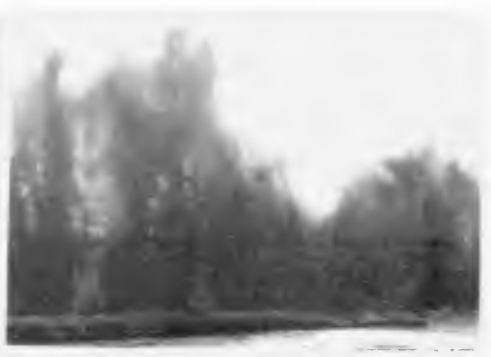

FIG. 18.

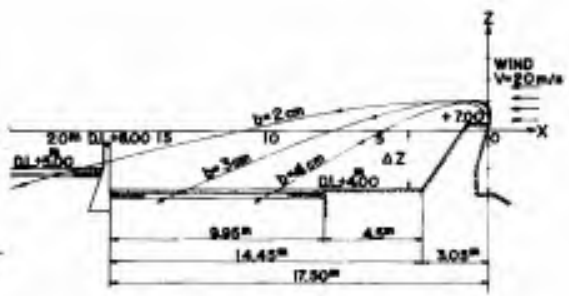

FIG. 21. - LOCI OF THE WALLS OF WATER OVERTOPPING THE SEA-WALL IN FIG. 20

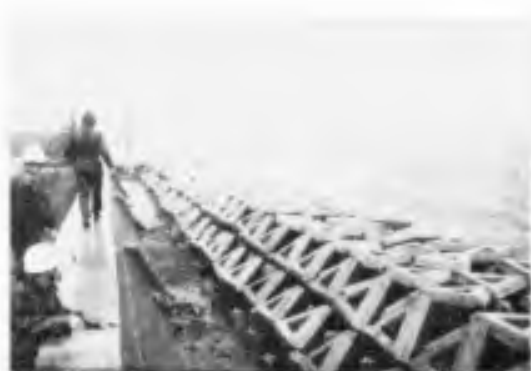

FIG. 23. - SEA-WAIL OF THE KANSAI E. P. CO.LTD. DURING A TYPHOON, 1961 